\title{
Liability of foreignness, natural disasters, and corporate philanthropy
}

\section{Murad A Mithani}

School of Business, Stevens Institute of Technology, Castle Point on Hudson, Hoboken, NJ 07030, USA

\section{Correspondence:}

MA Mithani, School of Business, Stevens Institute of Technology, Castle Point on Hudson, Hoboken, NJ 07030, USA.

Tel: 518.250.8917;

Fax: 201.216.8700;

e-mail: murad.mithani@stevens.edu
Received: 18 November 2014

Revised: 6 July 2017

Accepted: 27 July 2017

Online publication date: 11 September 2017

\begin{abstract}
This study examines how philanthropy can mitigate liability of foreignness (LOF) in the aftermath of a national disaster. A major disaster restructures the social landscape, creating an avenue for corporate contributions to play a role in recovery and relief efforts. This social restructuring offers a valuable opportunity for multinational enterprises (MNEs) to establish strong local ties. In turn, MNE contributions at such times have a stronger impact on their local acceptance. Thus, MNEs can use these events to strengthen their position in the community and mitigate LOF. Using the context of a national disaster in India, I test these arguments with a sample of 190 MNEs and 660 domestic firms. I found that in the aftermath of the disaster, the increase in MNE contributions was much larger and less strongly tied to promotional activities than the increase in contributions from domestic firms, and this difference persisted over time. Moreover, the performance implication of post-disaster philanthropy was stronger for MNEs than for domestic firms. These findings suggest that philanthropy plays a more strategic role for MNEs in the aftermath of a disaster and it has a pronounced effect on mitigating LOF.
\end{abstract}

Journal of International Business Studies (2017) 48, 94I-963. doi: | 0. I057/s4 | 267-0 |7-0104-x

Keywords: natural disaster; philanthropy; multinational enterprises; social restructuring; liability of foreignness; India

The online version of this article is available Open Access

\section{INTRODUCTION}

Liability of foreignness (LOF), defined as the social and cultural barriers that limit the embeddedness of non-local firms in the host environment, remains a critical concern for multinational enterprises (MNEs) (Zaheer, 1995, 2002). LOF manifests in the form of higher operating costs for MNE subsidiaries relative to domestic firms (Bell, Filatotchev, \& Rasheed, 2012). These costs can be particularly significant in emerging economies, whose stakeholders generally have a greater distrust of foreign firms (Kostova \& Zaheer, 1999), and especially in newly reformed economies, where direct access to foreign firms is a relatively recent phenomenon (Beugelsdijk \& Frijns, 2010). LOF makes it necessary for MNEs to work harder to legitimize their local presence, and pay greater attention to mechanisms that facilitate social integration (Nachum, 2003). Since philanthropy can be important in minimizing the perceived 
distance that separates MNEs from domestic firms (Bhanji \& Oxley, 2013; Crilly, Ni, \& Jiang, 2016), I argue that it can be used strategically by MNEs to reduce or even eradicate LOF, particularly in the aftermath of national disasters.

I refer to national disaster as one or more disasters (natural or otherwise) that solely or in conjunction have a disproportional impact on the lives and livelihoods of a significant portion of the national population (Glynn et al., 2003; Mitchell, 2006; Roberts, 2010). Such an event destabilizes the social and economic landscape and increases the openness of host communities to external help. It provides an opportunity for non-local firms to build strong local ties. Accordingly, I speculate that in the aftermath of a national disaster, MNEs will exhibit a larger increase in philanthropic contribution than domestic firms and this increase will have a positive effect on the relative performance of MNEs.

To test this hypothesis, I compared the philanthropic contributions of MNEs and domestic firms before and after a national disaster in India. I found that MNEs made larger philanthropic contributions than domestic firms in the aftermath of the disaster, and this difference between MNE and domestic firm philanthropy persisted over time. During this extended period, MNEs were relatively averse to complementing the increase in philanthropy with higher advertising expenditures compared to domestic firms. Moreover, I found that in comparison to domestic firms, there was a large increase in the relative performance of MNEs after the disaster and this increase was strengthened by philanthropic contribution. This suggests that MNEs effectively capitalized on the opportunity presented by the social restructuring that followed the disaster.

My study makes two contributions. First, I show that MNEs use philanthropy strategically, deploying contributions when they can have the largest impact on host communities. These contributions, in turn, mitigate the social and cultural barriers that lead to LOF as demonstrated by the significant improvements in MNEs' relative performance. Thus, I demonstrate that post-disaster philanthropy can serve as a valuable mechanism to mitigate LOF.

\section{THEORETICAL DEVELOPMENT}

\section{Disasters and Social Restructuring}

Disasters are "collective stress situations" that occur "when many members of a social system fail to receive expected conditions of life from the system.
These conditions of life include the safety of the physical environment, protection from attack, provision of food, shelter, and income, and guidance and information necessary to carry on normal activities" (Barton, 1969: 38). Source events for disasters may be political, economic, or natural in origin. In the case of natural disasters, on which this study focuses, the source event can include floods, droughts, earthquakes, and other exogenous shocks. Although the impact domain of a natural disaster is generally limited, one or more disasters can sometimes have a disproportionate impact on the social and the economic environment, creating effects on the lives of a major segment of the national population that last for several years. Such a disaster has nationwide implications, and it can induce significant changes in the social structure of the society (Gilbert, 1998; Kreps, 1985; Quarantelli \& Dynes, 1977).

A national disaster and its aftermath increase the community's expectations of support from the immediate environment (Aldrich, 2012). Those who are directly or indirectly affected by the calamity require material, financial, and emotional support to overcome the loss, rebuild their lives, and identify ways to resume day-to-day activities. Personal ties remain the primary source of emotional support; however, the government is typically expected to serve as the major source of financial and material help. Yet governmental institutions are rarely prepared for a major disaster (Drabek \& Key, 1976). Often, they are unable to stockpile sufficient resources or build needed skills to deal with calamities, especially in emerging economies where national institutions are typically inefficient and unorganized (Khanna \& Palepu, 2013). Once a disaster occurs, this lack of institutional resources increases the need for alternate sources of support, which invokes a reevaluation of social choices and makes it necessary for the community to open itself to dependencies it might previously have resisted (Bates \& Peacock, 1993; Horlick-Jones, 1995). The affected communities and others interested in supporting them are driven to seek out individuals and organizations that can help in rescue and relief efforts. This need induces a change in community interactions with the environment, leading to a reevaluation of existing connections and triggering a social restructuring - a change in the configuration of social ties.

The social restructuring that follows a disaster facilitates the legitimization of new social objects (i.e., perceptions, practices, organizations, etc.) that can overcome the negative implications of a 
disaster. Johnson, Dowd, and Ridgeway (2006) explain that the legitimization of new social objects is a gradual process that occurs in four stages: innovation, local validation, diffusion, and general validation. During the first stage, i.e., innovation, a social object that is capable of addressing one or more structural or environmental constraints experienced by the society gains greater visibility. In the second stage, local actors emerge who find the social innovation particularly valuable. These actors become a source of its initial validation. In the third stage, local actors help diffuse the social object to the wider environment. And in the fourth stage, which marks a culmination of the process, the social object becomes validated by the wider society. At this point, the novelty of the social object is replaced by its incorporation into the collective reality. The new social object acquires widespread acceptance and becomes a part of the shared system of belief. Building on this model, I examine how the social restructuring that follows a national disaster can become a foundation for greater local acceptance of MNEs.

\section{Social Spaces and the Legitimation of MNEs}

A major disaster can reframe the social perceptions regarding MNEs. The general tendency to view foreign firms as distant, passive, and insensitive to local needs can be replaced by the expectation that MNEs' financial prowess and global experiences make them critical partners for the much needed recovery and relief efforts. It allows MNEs to be viewed as a new social object, framed in terms of their capacity to save and improve lives rather than as a socially or culturally distinct entity that is primarily focused on economic success (Amaeshi, Adi, Ogbechie, \& Amao, 2006). However, the diffusion of this perception among the masses is not immediate. It is often led by the emergence of new social spaces that appear in response to the crisis (Quarantelli, 2000).

Social spaces are a microcosm of values, relationships, and implied or articulated structures (Savage $\&$ Silva, 2013). These spaces are not necessarily physical embodiments of preexisting social units, such as the family; rather, they exist as cognitive models for behavioral expectations centered on a shared objective (Pescosolido \& Rubin, 2000). A classroom, a church, and an Internet chatroom are all examples of social spaces, as is the line to receive relief goods. The groups that inhabit these spaces develop norms focused on the fulfillment of an underlying goal (Fisher \& Naumer, 2006). While these norms are often influenced by the larger society, the relationship is reciprocal; these spaces allow the individuals and groups associated with them the freedom to pursue interests that defy prevailing social orientations, and the values organized within them feed back into the generalized social structure. In other words, social spaces may harbor different sets of values than those accepted by the wider social and cultural environment and they may act as catalysts for changes in the more widely accepted norms (Lefebvre, 2009). In essence, social spaces can be viewed as communal discontinuities that reach out to affect the wider set of relationships prevalent in the society and the effectiveness of these spaces depends on the extent to which they succeed in fulfilling the underlying goals. The primary goal of social spaces that emerge in the aftermath of a major disaster is the identification of urgent needs, facilitation of the flow of material and financial help, and to serve as a point of contact for those who may otherwise have limited access to the region (e.g., Tilcsik \& Marquis, 2013: 115). Although the role of these groups diminishes as the community becomes more connected to new partners and the narrative crafted within these spaces is entwined with the communal identity (Chamlee-Wright \& Storr, 2011), these groups provide the local validation necessary for MNEs to be viewed as reliable partners and help the diffusion of new ties that go beyond the traditionally accepted interactions (Berkes, Colding, \& Folke, 2002).

The opening provided by social spaces serves as an avenue for foreign firms to interact with the community in new ways (Oliver-Smith, 1996). Instead of a relationship centered on products and deliverables, local validation makes it possible for MNEs to start building more personal ties. They allow MNEs an opportunity to better understand local preferences, respond in ways that these communities appreciate, and build rapport that can help reduce the social and cultural barriers underlying LOF (Pant \& Ramachandran, 2017). With greater diffusion of a renewed perception regarding MNEs, social spaces help ease the apprehensions about foreign entities (Mishina, Block, \& Mannor, 2012). Even when the role of social spaces is diminished, this validation enables host communities to appreciate a broader engagement with the external environment. Thus, the implications of social spaces continue beyond the immediate aftermath of the disaster. They provide a narrative that eventually becomes part of the communal 
identity (Chamlee-Wright \& Storr, 2011) and strengthens the links between the local environment and the foreign firms.

This development is highly consequential for the community because it allows access to resources that might otherwise not be available, especially resources held by MNEs. MNE involvement has been shown to be an important factor in limiting the ramifications of a major disaster (White \& Lang, 2012). MNEs bring important assets to the disaster response effort (Aldrich, 2012; Bhanji \& Oxley, 2013; Valente \& Crane, 2010), which among other things, include the much needed financial contributions (European Foundation Centre and Council on Foundations, 2007). Thus, social restructuring facilitates the creation of new social spaces that connect communities to MNEs. This connection has benefits in both directions: it helps communities overcome the deficits in recovery and relief operations and it also allows the firms to deploy philanthropic assets effectively for a stronger engagement with the community.

Since global experiences make MNEs more cognizant of the extent to which monetary contributions are essential for a meaningful impact, they are sensitive to the role of philanthropy in the aftermath of a disaster. These insights are less readily available to the domestic firms because large-scale disasters do not typically affect a region very frequently (Webb, Tierney, \& Dahlhamer, 2000). This marks a distinction between MNE and domestic firms' philanthropic responses in the aftermath of the disaster. In the following hypotheses, I examine how the choices made by MNEs and domestic firms continue to differ and eventually become a source of a decrease in LOF after a national disaster.

\section{Expansion of Social Ties}

In the aftermath of a disaster, domestic firms generally rely on historical ties to understand local needs. Their established networks remain the primary source of communication and engagement. Although the frequency of interaction is likely to increase, it has a limited effect on the nature of existing relationships. In contrast, MNEs, which have less well-developed ties to the community, must look to emergent social spaces to build the knowledge base needed to navigate the social and cultural terrain (Quarantelli, 2000) and know where to direct their philanthropic efforts. This greater MNE engagement with changing social structures leads to both public and private benefits (Baron, 2013; Luo, 2006).
The public benefits emerge from greater local access to the financial and organizational resources held by MNEs, which can enable a more rapid recovery from the disaster and create long-term connections that provide ongoing support to the community. MNEs gain private benefits in the form of a stronger social reputation (Strike, Gao, \& Bansal, 2006), which can help mitigate LOF. However, to gain this benefit, MNEs must take into account two mutually reinforcing considerations. First, a firm's legitimacy within the community is contingent on its responsiveness to the expectations of the new social spaces (Bhanji \& Oxley, 2013). These groups not only serve as "reputational intermediaries," connecting the MNE to the rest of the community (Bell et al., 2012), but also help establish the MNE's long-term credibility (Berkes et al., 2002). Thus, it is critical that MNEs respond to emergent social spaces and their norms in a way that nurtures faith in their intentions (e.g., Etzioni, 1975). Particularly in emerging markets, the suspicion with which host communities often view foreign firms makes it necessary for MNEs to demonstrate a very visible philanthropic engagement (Eden \& Miller, 2004; Kostova \& Zaheer, 1999), both to establish their commitment to providing material help and to allay concerns regarding their lack of local sensitivity (Zhang \& Luo, 2013). Second, MNEs operate in multiple markets and thus are less vulnerable to a change in the economic environment of a single host country (Dahan, Doh, \& Guay, 2006; Geppert, Matten, \& Walgenbach, 2006). This relative immunity from immediate financial distress makes them less concerned about the viability of the corporation, and hence freer to provide monetary support (Christmann \& Taylor, 2001; also see Patten, 2008).

Domestic firms may find it more difficult to take advantage of the social restructuring for a number of reasons. First, their relative lack of experience with disasters is compounded by conflicting expectations. On the one hand, the wake of a disaster brings an overwhelming demand for charitable contribution (Galaskiewicz, 1997). Local ties and domestic shareholding increase the pressure on domestic firms to undertake relief efforts to repair the fabric of the society in which they exist (Babiak \& Wolfe, 2006; Muller \& Whiteman, 2009). On the other hand, this increased expectation is accompanied by a need for financial restraint (Lines, 2004) since the upending of the local economy also destabilizes the firm. As local markets are materially and symbolically central to domestic firms' 
operations (Rugman, 2005), the shift in economic sentiment wrought by a disaster and the resulting uncertainty induces in domestic firms a calculus of consequences (Henisz, Dorobantu, \& Nartey, 2014). These firms must contend with greater ambiguity and as a result often delay long-term commercial investments and see a decrease in expectations for financial performance (Berkman, Jacobsen, \& Lee, 2011; Shan \& Gong, 2012). These economic pressures and uncertainties make domestic firms' future relatively unclear (Muller \& Kräussl, 2011). Thus, just when corporate philanthropic contribution is most needed, domestic firms are at the most risk (Tilcsik \& Marquis, 2013) and thus less able to provide the needed support.

This conflict - between a greater pressure to give and economic conditions that demand greater restraint in giving - makes it likely that, in the aftermath of a major disaster, domestic firms' philanthropic contributions will exhibit a relatively limited increase, even as MNEs increase their contributions more dramatically. Taken together, this confluence of forces suggests the first hypothesis:

Hypothesis 1: Subsequent to a national disaster, the increase in philanthropic contributions will be larger for MNEs than for domestic firms.

\section{Initial Skepticism Towards MNEs}

In the wake of a disaster, despite the urgent need for contributions, the wider community may not immediately embrace the ties introduced by the new social spaces (Oliver-Smith, 1996). The social and cultural differences that contribute to LOF, combined with the limited history of interaction, make it difficult for community members to understand the philanthropic motivation of MNEs seeking to connect. While each wave of diffusion of the value of MNE contribution encounters lower resistance, it requires a consistent demonstration of credibility (Johnson et al., 2006). This makes it necessary for MNEs' to ensure that they continue to appear as reliable social partners and their philanthropic choices are visible as a selfless act aimed towards benefiting the local population (Walker \& Zelditch, 1993). This suggests that compared to domestic firms, MNEs will not only seek to make larger philanthropic contributions as hypothesized earlier, but they will also be more cautious with complementary choices that can undermine their generosity. One such choice pertains to advertising expenditures. Despite the public benefits of philanthropy, corporate advertisements can make local communities skeptical whether the MNE is acting from a genuine concern or is merely seeking a tool for self-promotion (Fry, Keim, \& Meiners, 1982).

Indeed, MNEs have strong motivation to use their philanthropic work for self-promotion. The promotion of a firms' role in disaster recovery can yield significant social and financial capital; an increase in philanthropy can yield an economic advantage when combined with increased advertising expenditures (Aldrich, 2012). Even when social responsibility is not central to the promotional message, charitable acts are more noticeable for firms that are frequently visible in the media (File \& Prince, 1998; Varadarajan \& Menon, 1988). This feedback between advertising and philanthropy can be beneficial for a firm's financial performance (Brik, Rettab, \& Mellahi, 2011; Drumwright, 1996; Servaes \& Tamayo, 2013). However, markets are unlikely to respond positively when the social concern is perceived as an ingratiatory tactic (Patten, 2008) or a tool for self-promotion. This effect can be stronger and therefore more alarming for MNEs if local communities come to view their philanthropic contribution as a self-serving goal. MNEs can not only lose the support of social spaces that legitimize their local presence, it may also reinforce the hostility that leads to LOF. Thus, despite the potential benefits of increased advertising investments in conjunction with large philanthropic contributions, global experiences are likely to inform MNEs regarding the negative societal implications of complementarity (Godfrey, 2005; Patten, 2008). Accordingly, MNEs' relatively precarious relationship with the host environment will make them wary of integrating philanthropic choices with promotional activities (see Harjoto \& Jo, 2011). At the same time, a lack of complementarity is likely to be reinforced by the difficulty of making large unplanned expenditures in the context of a complex, geographically dispersed organization (Carrigan, 1997; also see Moir \& Taffler, 2004: 150). The geographical divide between local operations and the central office limits the firm's flexibility to rapidly escalate monetary commitments (Strike et al., 2006), implying that a sudden increase in philanthropic contributions will require a corresponding curtailment of other expenditures. Given the higher penalty of deceit to which they are subject and the logistical difficulty of escalating spending as a whole, I predict that MNEs will find it convenient to divert their advertising funds to 
philanthropic aims. ${ }^{1}$ It can allow MNEs to abide by the expectations of emergent social spaces and exhibit allegiance to local values and beliefs (see Walker, 2004; Zelditch, 2001). This does not imply that foreign firms will completely avoid promoting their social activities. Rather, I argue that MNEs will exhibit considerable restraint in complementing philanthropic work with promotional ends, and this can manifest either as a decrease or as a relatively limited increase in MNE advertising.

In contrast to MNEs, domestic firms are less concerned about a social backlash from promoting their philanthropic work (Wagner, 2010; also see Surroca, Tribó, \& Waddock, 2010). Community stakeholders are generally more willing to accept local producers' efforts to engage as authentic (Crilly et al., 2016); strong local ties can give a domestic firm greater freedom to manipulate "its relationships to its own ends" (Bhanji \& Oxley, 2013: 297), and allow them to use philanthropy as an investment in self-promotion. Thus, domestic firms are less likely to be inhibited in increasing their advertising expenditures to complement an increase in charitable contributions (Siegel \& Vitaliano, 2007; Zhang et al., 2010).

Contrasting pressures and expectations, then, will lead MNEs and domestic firms to treat advertising spending differently in the wake of a disaster. While MNEs are likely to restrain (i.e., either decrease or limit the increase in advertising expenditures) due both to sensitivity to local social concerns and to logistical difficulties, domestic firms will be more free in strengthening an increase in advertising expenditures along with the increase in philanthropic contributions. These differing circumstances lead me to predict that while domestic firms' philanthropy will be complemented by an increase in advertising, in comparison, MNE philanthropy will be accompanied by a relative decrease in advertising expenses:

Hypothesis 2: Subsequent to a national disaster, the difference between MNE and domestic firm philanthropic contributions will be negatively moderated by advertising expenses.

\section{Accumulation of Trust over Time}

Consistent interaction over time generally helps diminish the initial skepticism that inhibits local acceptance of foreign firms and leads to LOF (Zaheer \& Mosakowski, 1997). As MNEs demonstrate allegiance to the community's ideals, the local population is likely to find it increasingly easier to trust the firms' intentions. At the same time, in the context of a disaster, the return to normalcy in social spaces can lead to the reestablishment of social and cultural barriers; persistent engagement is required to refresh the social ties established in the disaster period (Mata \& Freitas, 2012). I argue that in order to maintain the transition from local to general validation (Johnson et al., 2006), MNEs will sustain an escalated philanthropic commitment for a significant period after a disaster (see Luo, 2006). This extended engagement will ensure that MNEs remain strongly embedded in the social fabric. The continued engagement will provide a further feedback benefit, enabling the firm to develop a deeper understanding of the concerns of local audiences and maintain an avenue for ongoing engagement (Mishina et al., 2012), providing opportunities to continue to diminish LOF. Thus, as the intense need for immediate relief by the community is replaced by an expectation of long-term institutional development (Barton, 1969), MNEs will continue to respond through philanthropic contributions at a higher level than before the disaster (Child \& Tsai, 2005; Dahan et al., 2006; Khanna \& Palepu, 2013).

As the disaster becomes a distant memory, however, domestic firms have little to gain from continuing to escalate their philanthropic commitments (e.g., Tilcsik \& Marquis, 2013). With consumers and the wider society paying less attention to the disaster and its aftermath, a visible philanthropic commitment becomes less valuable for promotion and so loses its strategic value (File \& Prince, 1998). Moreover, as governmental agencies become equipped to handle relief activities, there are fewer areas where domestic firms can have a meaningful effect (Henderson, 2007). As a result, the philanthropic commitments of domestic firms are likely to diminish over time (Bin \& Edwards, 2009) and these firms will limit further growth in contributions (Glynn, 2008). The difference between MNE and domestic firm philanthropy may not last forever, but, I argue, it will persist for some time after the disaster. ${ }^{2}$

Thus these arguments suggest that while the difference in philanthropic contributions between MNEs and domestic firms will be visible in the immediate aftermath of the disaster when both types of firms are equally likely to be socially engaged. However, this difference will become more significant and it will persist over time as MNEs continue to work to overcome LOF by solidifying general validation while domestic firms 
see limited benefit from continuing at a heightened level of engagement. These differing motivations lead to my third hypothesis:

Hypothesis 3: Subsequent to a national disaster, the difference between MNE and domestic firm philanthropic contributions will increase and remain persistent over time.

\section{Development of the Potential for Reciprocity}

After a disaster, social restructuring increases the philanthropic role of foreign firms and provides an opening for them to engage more productively with local communities. That greater engagement is likely to yield direct benefits, in the form of reductions in the costs typically associated with LOF, such as discriminatory pricing by suppliers, stringent regulatory control by local authorities, and a lack of brand recognition by consumers, as well as a general lack of perceived legitimacy (Eden \& Miller, 2004; Mezias, 2002; Zaheer, 1995). Furthermore, this trend is to some extent self-reinforcing. As a higher level of ongoing engagement allows an MNE to understand local expectations more clearly, the firm will become more effective in responding to local social needs (Pearce, 2003). Thus, MNEs' initial validation by emergent social spaces and the subsequent general validation by the wider community can lead to the development of a stronger alignment between MNE commitments and local expectations. The congruence will optimize the social impact of MNEs, giving greater legitimacy to their philanthropic choices (Godfrey, 2005), and further mitigating LOF. It can turn the skeptical local reception into MNEs being viewed as a taken-for-granted social object by the host environment (e.g., Roy, 1999).

On the other hand, domestic firms are not subject to the costs associated with LOF. So, while MNEs may harvest concrete benefits from ongoing philanthropy and growing local acceptance, domestic firms will have to contend with the increased economic pressure and uncertainty generated by the disaster and its aftermath, forces MNEs will be less vulnerable to, both because of their global nature and because of the diminishing cost of doing business engendered by the mitigation of LOF. The joint implication of diminishing legitimacy constraints for MNEs and increasing economic constraints for domestic firms is that MNEs will gain disproportional performance benefits, relative to domestic firms, from the social restructuring that accompanies a disaster. These benefits will mitigate the difference in performance between MNEs and domestic firms.
These predictions offer a direct test of my argument with regard to the effect of social restructuring. If social restructuring increases the openness of host communities to MNE presence, this should lead to a general decrease in LOF. Moreover, since this engagement escalates MNEs' philanthropic commitment and brings the contributing firms in greater contact with the local communities, this in turn implies that MNE philanthropy will accentuate the increase in performance compared to domestic firms after the disaster. This reasoning leads to my final hypotheses:

Hypothesis 4a: Subsequent to a national disaster, there will be an increase in the performance of MNEs compared to that of domestic firms.

Hypothesis 4b: Subsequent to a national disaster, the difference between MNE and domestic firm performance will be positively moderated by philanthropic contributions.

\section{DATA AND METHODS}

\section{Empirical Setting}

I use the context of India to test my hypotheses. This setting confers three major advantages. First, India's aversion to foreign firms began soon after its independence from the British Empire in 1947 when it adopted a socialist model that focused on the eradication of poverty through an equitable distribution of wealth. In this model, the "royalties and profits collected by the private foreign companies" were viewed as "pure loot" and its first prime minister, Jawaharlal Nehru, even requested the Cabinet to find ways to eliminate such payments (Gopal, 1984: 112). Accordingly, foreign equity investment in a firm operating in India was limited to 40 per cent. This restriction made exports and joint ventures the preferred mode of foreign entry, but many MNEs avoided the Indian market altogether (Panagariya, 2008; Pant \& Ramachandran, 2017). ${ }^{3}$ Market liberalization reforms starting in 1991 allowed the foreign equity limit to be increased to 51 per cent and eventually higher, ${ }^{4}$ but also led to severe criticism from domestic enterprises and affiliated associations. In order to retain their advantage, local producers claimed that foreign firms jeopardize an economy by eliminating local jobs and transferring capital that can be deployed locally into off-shore accounts. The rhetoric of that criticism resonated with the public and it strengthened the view that MNEs are more 
interested in immediate gains and their presence jeopardizes the traditional values that are integral to the society (Singh, 2005). Although these protests did not deter market reforms, they reinforced the traditional hostility against foreign firms. Thus, while market liberalization has made it possible for MNEs to establish a direct presence in India, LOF remains a critical concern (Jenkins, 1999).

A second benefit of this setting is its salience for the study of the economic and social impacts of natural disasters. Despite its rapid growth, the Indian economy is characterized by weak institutions (Ghoul, Guedhami, \& Kim, 2017; Khanna \& Palepu, 2013) which are severely tested during natural disasters. Given its geographical size, natural disasters are not a rare occurrence. This frequency allows me to examine post-disaster philanthropy not as a hasty reaction but as a more developed response. A series of such disasters occurred in 2001, beginning with a massive, magnitude 7.7 earthquake in the state of Gujarat on January 26. The earthquake, which lasted for more than two minutes, resulted in the deaths of more than 20,000 people; another 167,000 were injured and approximately 1 million built structures were damaged or destroyed, including more than 11,500 schools, two very large hospitals, more than 1,200 clinics, and hundreds of reservoirs that supplied water to urban and rural areas (Asian Development Bank \& The World Bank, 2001). The earthquake had a huge economic impact, as reported by the Indian Ministry of Home Affairs, it:

\footnotetext{
[E]roded nearly two percent of the GDP of the State of Gujarat-one of the most industrially advanced States in the country ... [it] caused nearly ten thousand industrial units to go out of production as it struck the industrial heartland of the State. The total economic loss was assessed at over Rupees five thousand crores [\$1.05 billion]. The entire spectrum of industries including the lifeline structures like bridges, roads, power, rail network telecommunication, air control towers and aerodromes suffered damages and hampered restoration and rehabilitation activities. (Issar \& Mathur, 2004: 9) ${ }^{5}$
}

The January earthquake was followed in July and August by devastating flooding in Orissa (now Odisha), a northeastern state; the fifteen floods between July 8 and August 20 were the worst in Orissa's recorded history (BBC, 2001a). They submerged 25 of the state's 30 districts, affected almost 8 million people, and led to agricultural losses valued at 150 billion rupees, or about $\$ 3.15$ billion (Mirza, Ahmed, \& Ahmad, 2007: 199). Eighty people died (BBC, 2001a). Floods in the state of
Bihar, also in August, killed 89 people and affected more than half a million, and resulted in 4.9 billion rupees, or approximately $\$ 103$ million, in crop damage (Hindu, 2001). A fourth disaster occurred in Andhra Pradesh in October, when heavy rains combined with a cyclonic storm led to the loss of 119 lives and damaged 111,340 houses (National Disaster Risk Reduction Portal; Andhra Pradesh).

These disasters were followed by a massive relief effort that engaged central and state governments; local and international civil society organizations such as the Indian Red Cross Society, Save the Children, Oxfam, and Action Aid; and individuals and corporations (BBC, 2001b). The devastation was widespread as the earthquake and floods hit large populations in four states, forced the relocation of millions of people for several months, and ruined farmland during the peak agricultural season. The financial impacts reverberated for several years. Several relief organizations, struggling to respond effectively, moved resources across affected regions, overcoming resource constraints in one region by reallocating funds received for the other regions (Indian Red Cross Society, 2002), essentially treating all four events as a single national disaster. I follow suit in my analysis, considering the four disasters as a single crisis event.

A third advantage of the Indian context is the uninhibited access to data on philanthropic contributions. Publicly listed firms in India are required to disclose financial charitable donations in their annual reports. This ensures that all philanthropic contributions of sampled firms are captured and there is no truncation effect, which can be a source of spurious inference.

I limit my focus on financial contributions by publicly listed firms. A major advantage of financial contributions is that they are quantifiable and comparable, offering a common baseline, and because of the difficulties associated with collecting data on and accounting for non-monetary contributions, such as organization-wide goods donation campaigns, crisis response expertise, or paid leave extended to employees for participating in relief activities. Furthermore, financial contributions are the most valuable kind of assistance; they are easy to receive, store, and transmit, and they can be exchanged for whatever goods or services recipients may require, and they provide amplified benefits in the form of economic support for the affected communities, where the funds are spent. As the 
European Foundation Centre and the Council on Foundations (2007) explain:

\begin{abstract}
Cash assistance is nearly always preferable to donated goods, because it allows for maximum flexibility to meet the highest priority needs and can be used to purchase required items in the disaster-affected area, thereby boosting the local economy while minimizing transport costs. (p. 14)
\end{abstract}

Moreover, financial philanthropy is the largest form of corporate social support during disasters (Aeberhard, 2008; European Foundation Centre and Council on Foundations, 2007).

The inclusion of only publicly listed firms in my sample limits an understanding of the behavior of private enterprises. However, listed firms in India are responsible for more than 80 per cent of total corporate taxes, making them highly representative of the overall economy (see Chari \& David, 2012; Khanna \& Palepu, 2000). Thus, I believe that the tradeoffs I have made are reasonable and my sample offers an effective dataset to compare the philanthropic choices of MNEs with those of domestic firms.

\section{Sample}

I collected my data from the Center of Monitoring Indian Economy's (CMIE) Prowess database. This database is widely used by scholars (Khanna \& Palepu, 2000; Lamin, 2013; Vissa, Greve, \& Chen, 2010). It reports the activities of firms specific to their operations in India and allows an effective comparison of the choices made by domestic firms and MNEs. In addition to firm financial indicators, Prowess also captures philanthropic contributions. All values are in millions of Indian rupees, unless otherwise indicated. To distinguish between philanthropic contributions prior and subsequent to the disaster, I chose a four-year interval divided equally around the event: the periods 1999-2000 and 2001-2002. To test my hypothesis regarding temporal persistence of the difference between MNE and domestic firm philanthropy, I extended the sample by an additional two years until 2004. This choice balances proximity with sufficiency of coverage and allows me to examine both immediate and long-term contributions.

During the sample period, one other major disaster affected India. It was a cyclone in 1999 that killed almost 10,000 people in Orissa. However, its impact domain was relatively small, both geographically and in the duration of effect, and the national response did not extend to large parts of the population (Thomalla \& Schmuck,
2004). In contrast, the events of 2001 led to extensive calls for government and private intervention. It catalyzed social restructuring and escalated the demand for external help (Issar \& Mathur, 2004). To more clearly understand the extent to which the disasters in 2001 were more critical for the country, I compiled the list of all major and minor disasters in India during the sample period (plus one preceding and one following year) to determine the relative change in the difference between MNE and domestic firm philanthropy (Difference-in-Difference or DiD) for each year in the data relative to the previous year. The trend is shown in Figure 1. It illustrates that the difference between MNE and domestic firm philanthropy experienced the most significant change between 2000 and 2001, validating my argument that the national disaster of 2001 had a strong effect on MNE philanthropy. I repeated a similar test for performance (not shown here) and found that the difference between MNE and domestic firm performance also experienced the most dramatic change immediately after the disaster, between 2000 and 2001. Appendix A includes a summary of the impact of all major and minor earthquakes and floods in India between 1998 and 2003 .

Since the fiscal year for Indian firms ends in March, some immediate relief following the Gujarat earthquake is likely to appear in my baseline period, which ends on March 31, 2001 and corresponds to the fiscal year 2000. However, I believe that those amounts represent only the most urgent contributions and the majority of donations are likely to be recorded in later periods. To the extent that some philanthropic contributions may appear in the period preceding March 2001, this raises the baseline effect, making it more difficult to validate my hypotheses and thus yielding a more stringent empirical test.

\section{Measures}

\section{Dependent variables}

My measure of philanthropic contribution follows that of the Indian Companies Act of 1956 (293B): any "donation, grant, gift, help, assistance, aid, charity, alms, or otherwise, given for any charitable, social, educational, national defence, scientific, purpose or [to] any organisation or activity (formal or informal) having the object of promoting commerce, art, science, religion, charity or other useful object." Thus, I include in the measure all financial 


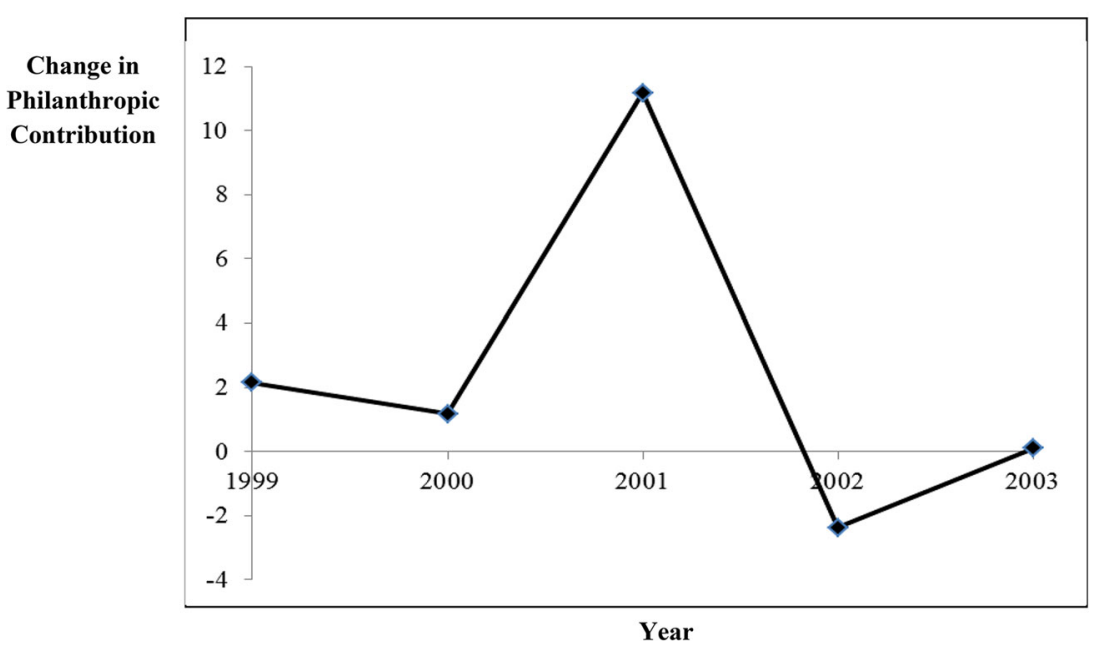

Figure $1 \mathrm{DiD}$ estimates at alternate break points for MNE-domestic firm philanthropy. Note: The figure reports change in the philanthropic contributions of MNEs relative to domestic firms in each year $(t)$ relative to the previous year $(t-1)$. It shows that the largest relative increase in MNE philanthropy occurred immediately after the 2001 national disaster.

charitable donations in the periods of interest, without differentiating disaster-related donations from other philanthropic spending. This decision reflects the nature of the data available in the Prowess database. Although some firms do specify funds spent on disaster-related activities versus other philanthropic efforts in their annual reports, most do not. This limitation is not critical, since my argument is centered on changes in philanthropy that accompany the disaster. As I discuss later, my analytical approach examines this change after controlling for the historical trend in philanthropic contributions.

The research on LOF measures the relative difference between MNE and domestic firm performance in two ways - by comparing the gross profit of a foreign firm relative to the mean gross profit of all domestic firms in the industry (Zaheer, 1995; also see Miller \& Parkhe, 2002) and by comparing the performance of a subsample of foreign firms with that of a subsample of domestic firms (Zaheer \& Mosakowski, 1997). The latter approach corresponds to the use of a dummy variable that allows the evaluation of firms from one group (i.e., MNEs) relative to firms from the other group (i.e., domestic firms). I combine these approaches and operationalize relative performance as the gross profit of a sampled firm relative to the industry ${ }^{6,7}$ and in the analytical model, use a dummy variable to distinguish between MNEs and domestic firms. In calculating industry gross profit, I include all domestic firms reported in Prowess and identify the industry boundary corresponding to the four-digit SIC classification commonly used in the United States (e.g., Nachum, 2003; also see Chacar \& Vissa, 2005).

\section{Independent variables}

There are several approaches to identify multinational enterprises (Dunning \& Lundan, 2008: 3). However, my focus is not simply on establishing a foreign association. Rather, my interest is to identify firms where a foreign corporate entity acts as the controlling body and is actively involved in operations. To establish this, I consulted CMIE staff, who acknowledged that there is no foolproof way of identifying the extent of multinationality for listed firms in India. Based on these discussions, I concluded that the most conservative approach was to restrict the identification of MNEs to firms whose proportion of shares held by foreign corporate entities exceeded 50 per cent. This ensured that my sample was restricted to MNEs that are actively controlled by non-domestic corporations. Consequently, firms with a majority of shares held by foreign institutional or individual investors are excluded from the sample. This approach led to the identification of 190 firms, including large, well-known multinationals such as Hindustan Unilever, Procter \& Gamble, and GlaxoSmithKline, as well as smaller and less well-known firms.

To ensure a comparable sample of domestic firms, I extracted firms whose proportion of shares held by domestic corporate entities exceeded 50 per cent. This resulted in the identification of 660 
firms, including firms such as Tata Coffee, Aditya Birla Chemicals, and Advanced Micronic Devices. In total, my sample includes 850 firms with 3,118 observations. It extends to 3,946 and 4,775 observations, respectively, when examining the persistence of the difference between MNE and domestic firm philanthropy (i.e., in the 3rd and the 4 th year after the disaster).

To distinguish between the interval prior and subsequent to the disaster, I operationalize period as an indicator variable, set at 1 for years 2001 and onwards and 0 otherwise. For the three-way interaction in hypothesis 2, I use the value of advertising expense as stated in the annual reports.

\section{Controls}

Since philanthropic contributions can be influenced by firm size, I control for the log of sales (+1) (Crilly et al., 2016). I also checked by using assets and found the results to be substantively similar. Another important control is the volume of a firm's revenues from foreign markets; considering this factor also controls for domestic multinationals (Chittoor, Sarkar, Ray, \& Aulakh, 2009; Michel \& Shaked, 1986). I incorporate this control by using the ratio of a firm's exports to total sales.

The availability of excess resources, or slack, can also affect philanthropic choices (Brown, Helland, \& Smith, 2006; Seifert, Morris, \& Bartkus, 2004; also see Mata \& Freitas, 2012). To capture this, I include both unabsorbed and potential slack. Unabsorbed slack is computed as the ratio of current assets to current liabilities, and potential slack is the ratio of total debt to equity. ${ }^{8}$ Previous studies have found that engagement in $R \& D$ can be associated with charitable giving (McWilliams \& Siegel, 2000); I control for this effect by capturing R\&D expenses. I did not use R\&D intensity due to its strong correlation with the slack variables. In addition, it is quite possible that host country experience may affect the implication of my arguments. I incorporate this possibility by including local experience as a control. It is operationalized as the number of years since the firm was incorporated in India. For domestic firms, incorporation generally represents the year of founding. For MNEs, incorporation represents the year in which the firm first started its business in India.

Indian firms are often affiliated with business groups (Khanna \& Palepu, 2000; Vissa et al., 2010). As group-level charity may have an effect on affiliated firms' philanthropic contributions, I include a variable $B G$ philanthropic contribution to capture the total philanthropic contribution of a business group less that of the focal firm (see Miller, Lee, Chang, \& Le Breton-Miller, 2009). ${ }^{9}$

Since the effect of a disaster may vary across firms, largely due to geographic proximity to the impact zone, and those that are directly affected may exhibit different responses than those that are more geographically distant, I control for location with a dummy variable, impact zone, set as 1 for firms with a registered Indian head office in one of the affected cities and 0 otherwise (also see Crampton \& Patten, 2008). The proportion of my sample located in affected cities is reported in Appendix B. I checked this result with an alternate measure that used the state boundary (i.e., Gujarat, Orissa, Andhra Pradesh, or Bihar) to identify the impact zone; this measure yielded identical results. Finally, to control for variations in technology and market, I use industry dummies in all the models (McWilliams \& Siegel, 2001).

Table 1, which reports the mean values for MNE and domestic firm subsamples across all variables, shows major variations between the two groups of firms. This raises the question of whether there may be systematic differences between MNEs and domestic firms that lead to their philanthropic choices. There are two common approaches to overcome these differences. The first is to create a matched sample with comparable values across at least one of the key variables (e.g., Doukas \& Lang, 2003). A second approach is to use an analytical model that controls for subsample differences during estimation, such as the difference-in-difference (DiD) model.

The DiD approach is considered more robust for two principal reasons. First, subsample means are inadequate in capturing underlying differences in

Table 1 Subsample means

\begin{tabular}{lrcc}
\hline Variables & MNE & Domestic & $t$-value \\
\hline Philanthropic contribution & 0.24 & 0.08 & $0.16^{\star *}$ \\
Advertising expense & 24.88 & 5.58 & $19.30^{\star * *}$ \\
Relative performance & 0.04 & 0.08 & -0.04 \\
Sales (Ln) & 6.73 & 5.25 & $1.48^{\star * *}$ \\
Exports/sales & 0.17 & 0.13 & $0.04^{\star * *}$ \\
Unabsorbed slack & 1.98 & 1.46 & 0.52 \\
Potential slack & 8.13 & 3.10 & 5.03 \\
R\&D expense & 4.70 & 1.11 & $3.59^{\star * *}$ \\
Experience & 28.54 & 25.18 & $3.36^{\star * *}$ \\
BG philanthropic contribution & 0.07 & 0.39 & $-0.31^{\star * *}$ \\
Impact zone & 0.04 & 0.04 & -0.01 \\
\hline
\end{tabular}

Note: ${ }^{* *} p<0.01 ;{ }^{* * *} p<0.001$. 
panel data. This is because, despite identical means, the variables may experience contrasting trends over time. Second, matched samples require the removal of observations, which not only reduces the sample size but can also introduce a sampling bias. This happens when the mean value of the focal variable in one or both subsamples experiences a drift, which can lead to a failure to represent the associated population parameter (Cram, Karan, \& Stuart, 2009). Given these constraints, I prefer the use of DiD. However, I also validate my findings through a matched sample. To create a matched sample, I mapped each MNE to a domestic firm from the same industry based on sales. Using this approach, I identified 53 MNEdomestic firm pairs with a total of 424 observations (530 observations for the 3rd and 636 observations for the 4 th post-disaster year). The results of this analysis, reported in Appendices C and D, are largely consistent with my findings.

\section{Analytical Model}

My aim is to compare the philanthropic contributions and performance of MNEs and domestic firms in the period after the disaster relative to their comparative differences prior to the disaster. The DiD model offers the most appropriate estimation technique for this analysis (e.g., Kacperczyk, 2009; Reeb, Sakakibara, \& Mahmood, 2012). DiD allows the examination of outcomes associated with a treatment group - i.e., MNEs - relative to a control group - domestic firms. In establishing this comparison, the outcomes are estimated for a significant difference after the focal event to understand whether they exceed the trajectory of their differences prior to the event. This makes it possible for me to infer whether MNE philanthropic contribution and performance differs significantly from that of domestic firms from 2001 onwards relative to the differences between the two groups prior to 2001. DiD offers statistical estimates for treatment and control group differences as a consequence of the event. If philanthropic contribution (or performance) maintains the historical trend and the treatment (MNE) and control (domestic firms) groups do not exhibit any meaningful change, then the estimation model fails to predict a significant effect. If there is a change, but the change in the treatment group is similar to that in the control group, this also leads to a failure to predict a significant effect. The only way to establish significance is for MNEs to exhibit a change in the outcome variable relative to the historical trend that is larger than the relative change exhibited by domestic firms. This eliminates the effect of subsample differences by using both domestic firm and MNE philanthropic history as the baseline effect.

DiD relies on the use of two distinct dummy variables; the significance of the DiD effect is ascertained by the interaction between the two dummies. In my case, these dummies include period, which differentiates observations subsequent to the event from those prior to the event, and $M N E$, which separates the treatment group from the control group. A significant interaction between MNE and period validates the two conditions identified above. This can be seen from the following equation, where $y$ represents the outcome variable (philanthropic contribution or performance) and $\beta_{3}$ is the coefficient capturing the joint effect of post-disaster implications for MNEs:

$$
\begin{aligned}
y= & \beta_{0}+\beta_{1} \times \text { period }+\beta_{2} \times M N E+\beta_{3} \times \text { period } \\
& \times M N E+\sum \beta_{k} \times \text { controls }+\varepsilon .
\end{aligned}
$$

The coefficient $\beta_{3}$ is significant only if the outcome variable for MNEs relative to domestic firms (DOM) is significantly different in the period after the disaster $\left(t_{2}\right)$ relative to their difference prior to the disaster $\left(t_{1}\right)$. That is

$$
\beta_{3}(\text { est })=\left(y_{\mathrm{MNE}_{t 2}}-y_{\mathrm{MNE}_{t 1}}\right)-\left(y_{\mathrm{DOM}_{t 2}}-y_{\mathrm{DOM}_{t 1}}\right) .
$$

When testing for moderating effects, the focus shifts to the interaction between the two dummies (period and MNE) in the presence of the focal variable (advertising expense or philanthropic contribution). This approach may be seen as the implementation of two-way fixed effects, across subject groups and across time intervals.

I run the estimation models by accounting for the longitudinal nature of the sample. For this, I use generalized least squares (GLS) models with random effects. These models allow me to account for the effect of multiple observations per firm. Although fixed effects models may also be viable, they exclude variables that are time invariant across the sample period (i.e., MNE), which makes them inappropriate for my analysis. In a separate analysis, I also checked the results using fixed effects and found them to be fully consistent. ${ }^{10}$ 


\section{RESULTS}

Table 2 presents the descriptive statistics and firstorder correlations. In Table 3, I test hypotheses 1 through 3 . In models $1-3$, I examine the predicted effects for the two years $t$ and $t+1$ after the disaster relative to the two years prior to the disaster. Model 1 includes only the baseline controls; their effects are consistent with previous research that shows that firms with higher sales and $R \& D$ expenses make larger philanthropic contributions. Model 2 tests the interaction between MNE and period. The positive and significant effect at $p<0.05$ shows that the relative increase in philanthropic contribution after the disaster is significantly larger for MNEs than for domestic firms. A unit increase in philanthropic contribution by a domestic firm is matched by about ten times the contribution by a MNE. This supports hypothesis 1 .

In model 3, I test for complementarity between philanthropic contribution and advertising expense subsequent to the disaster. The three-way interaction shows that MNEs that increased their philanthropic contributions exhibit a relatively smaller increase in advertising expenses compared to domestic firms. Interestingly, the analysis also shows that advertising is strongly associated with philanthropy, and after excluding MNEs, the sample of domestic firms appears to have complemented the increase in philanthropy with higher advertising expenditures after the disaster (period $\times$ advertising). However, MNEs that invest more in philanthropy exhibit a marginally smaller increase, almost 50 per cent lower than domestic firms, after taking into account their differences prior to the disaster (MNE $\times$ period $\times$ advertising). This supports hypothesis 2 at a significance of $p<0.001$.

An alternative explanation of this effect could be that the limited increase in MNE advertising is associated with the changes in marketing plans. That is, rather than greater sensitivity to local perceptions, MNEs may have decreased advertising due to an overall decrease in marketing activities. I evaluated this possibility by comparing the effect of advertising expense to another key component of the marketing budget, sales and promotional discount. The benefit of using this variable is that while sales and promotional discounts are coordinated with advertising expenditures for major marketing events, such as product launches, their emphasis on point-of-sale activities is seen by consumers as independent of the corporate brand (DelVecchio,

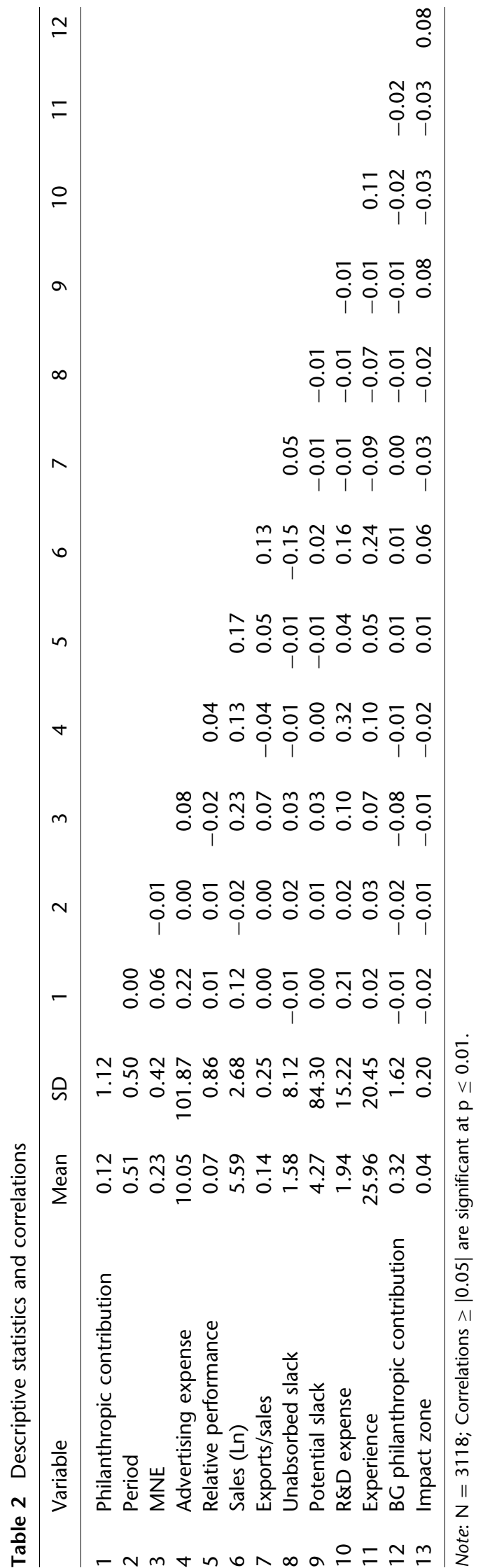


Table 3 GLS random effects regression models for philanthropic contribution

\begin{tabular}{|c|c|c|c|c|c|}
\hline \multirow[t]{2}{*}{ Variable } & \multicolumn{3}{|c|}{$t+1$} & \multirow{2}{*}{$\begin{array}{l}t+2 \\
4\end{array}$} & \multirow{2}{*}{$\begin{array}{l}t+3 \\
5\end{array}$} \\
\hline & 1 & 2 & 3 & & \\
\hline MNE $\times$ period & & $10.51^{*}$ & $10.65^{*}$ & $14.86^{*}$ & $21.11^{*}$ \\
\hline MNE $\times$ period $\times$ advertising & & & $-1.08^{* * *}$ & $-0.89^{*}$ & $-1.53^{* *}$ \\
\hline MNE & & 18.12 & $18.81^{*}$ & $21.76^{*}$ & $24.34^{*}$ \\
\hline Period & & 0.87 & 0.73 & 2.00 & 6.00 \\
\hline Advertising expense & & & $0.61^{* * *}$ & $0.64^{* * *}$ & $0.87^{\star * *}$ \\
\hline MNE $\times$ advertising & & & 0.02 & -0.001 & 0.10 \\
\hline Period $\times$ advertising & & & $0.60^{* *}$ & 0.22 & $1.00^{* * *}$ \\
\hline Sales (Ln) & $2.88^{*}$ & $2.56^{*}$ & 1.91 & 1.61 & $3.29^{*}$ \\
\hline Exports/sales & 1.02 & 0.53 & 2.9 & 2.11 & -11.9 \\
\hline Unabsorbed slack & 0.07 & 0.04 & 0.03 & 0.03 & 0.07 \\
\hline Potential slack & 0.0003 & -0.002 & -0.002 & -0.001 & -0.002 \\
\hline R\&D expense & $0.42^{\star *}$ & $0.40^{* *}$ & $0.38^{* *}$ & $0.33^{*}$ & $0.40^{*}$ \\
\hline Experience & -0.10 & -0.11 & -0.17 & -0.15 & -0.14 \\
\hline BG philanthropic contribution & 0.17 & 0.23 & 0.05 & 0.16 & $1.33^{*}$ \\
\hline Impact zone & -18.98 & -18.5 & -16.81 & -18.61 & -19.06 \\
\hline Industry dummies & Y & Y & $\mathrm{Y}$ & $\mathrm{Y}$ & $\mathrm{Y}$ \\
\hline Wald $\chi^{2}$ & $44.83^{* * *}$ & $49.93^{* * *}$ & $146.70^{* \star *}$ & $134.45^{\star * *}$ & $240.71^{* * *}$ \\
\hline$R^{2}$ & $0.11 \%$ & $0.28 \%$ & $2.68 \%$ & $2.06 \%$ & $3.34 \%$ \\
\hline$N$ & 3118 & 3118 & 3118 & 3946 & 4775 \\
\hline
\end{tabular}

Note: ${ }^{*} p<0.05 ;{ }^{* *} p<0.01 ;{ }^{* * *} p<0.001$.

Henard, \& Freling, 2006). Thus, a change in the marketing plan is likely to diminish the emphasis on advertising as well as on sales and promotional discounts, but a decreased corporate emphasis on self-promotion may only have a constraining effect on advertising. Examining the interactive effect of sales and promotional discounts on post-disaster MNE philanthropy, I found an opposite effect. While MNE advertising shows a negative relationship with philanthropy, MNE sales and promotional discounts show a positive relationship. This confirms that the decrease in MNE advertising after the disaster is independent of changes in other marketing activities, which validates my argument for MNEs' restraint on self-promotion. I have included this test in Appendix E.

Models 4 and 5 repeat the fully saturated model (model 3) for 3- and 4-year intervals after the disaster, respectively. The consistent and significant increase in the value of the coefficient for $M N E \times$ period supports hypothesis 3 . It shows that the difference between MNE and domestic firm philanthropy not only persists but it also widens over time (i.e., in the third and the fourth year after the disaster). For the interactive effect of advertising, the coefficient first increases (3rd year) and then decreases (4th year), which suggests a growing but less consistent restraint in MNEs' self-promotional preferences.
In Table 4, I test my final set of hypotheses. Model 1 includes the baseline controls, which show a significant effect for sales. Model 2 includes the post-disaster implications for the relative performance of MNEs; the positive and significant effect of $M N E \times$ period at $p<0.05$ supports hypothesis 4 a. It shows that the increase in MNE performance was almost 7 times to that of domestic firms after the disaster. It validates my argument that social restructuring mitigates LOF.

Model 3 includes the three-way interaction between MNE $\times$ period and philanthropic contribution. The positive and significant effect at $p<0.001$ supports hypothesis $4 \mathrm{~b}$ that philanthropy strengthens the acceptance of MNEs by the host community; after accounting for the mean effect, each additional unit of philanthropic contribution yields around 2 per cent further increase in relative performance. The evidence of social restructuring is also reinforced by the negative significance for MNE $\times$ philanthropic contribution, which indicates that, in general, MNE philanthropy backfires. That is, in the absence of a crisis, local communities are unlikely to exhibit the openness that contributes to an increase in MNE performance. Accordingly, philanthropy may largely be a cost, and in general, MNEs that do not invest into philanthropy perform better. Model 4 includes the interactive effect of advertising and it shows that the relative performance 
Table 4 GLS random effects regression models for relative performance

\begin{tabular}{|c|c|c|c|c|}
\hline Variable & 1 & 2 & 3 & 4 \\
\hline MNE $\times$ period & & $6.70^{*}$ & $7.09 * \star$ & $7.10 * *$ \\
\hline MNE $\times$ period $\times$ philanthropic contribution & & & $24.76^{\star * *}$ & $24.64^{* * *}$ \\
\hline MNE $\times$ period $\times$ advertising & & & & 0.02 \\
\hline MNE & & $-22.92^{\star \star *}$ & $-23.78^{* * *}$ & $-23.41^{* * *}$ \\
\hline Period & & 1.03 & 1.18 & 1.17 \\
\hline Philanthropic contribution & & & $2.25^{*}$ & 1.51 \\
\hline MNE $\times$ philanthropic contribution & & & $-9.17^{\star * *}$ & $-8.23^{\star * \star}$ \\
\hline Period $\times$ philanthropic contribution & & & -0.77 & -0.76 \\
\hline Advertising expense & & & & $0.10^{* *}$ \\
\hline MNE $\times$ advertising & & & & -0.13 \\
\hline Period $\times$ advertising & & & & 0.01 \\
\hline Sales (Ln) & $3.23^{* * *}$ & $3.72^{* * *}$ & $3.66^{* * *}$ & $3.50^{\star * *}$ \\
\hline Exports/sales & 5.73 & 6.39 & 6.80 & 7.31 \\
\hline Unabsorbed slack & -0.07 & -0.05 & -0.05 & -0.06 \\
\hline Potential slack & -0.002 & -0.003 & -0.003 & -0.003 \\
\hline R\&D expense & 0.08 & 0.10 & 0.09 & 0.08 \\
\hline Experience & -0.02 & -0.04 & -0.03 & -0.03 \\
\hline BG philanthropic contribution & -0.96 & -1.09 & -1.08 & -1.11 \\
\hline Impact zone & 2.51 & 2.13 & 2.93 & 3.14 \\
\hline Industry dummies & Y & Y & Y & Y \\
\hline Wald $\chi^{2}$ & $28.17^{\star * \star}$ & $37.53^{\star * *}$ & $78.25^{\star \star \star}$ & $84.47^{\star \star \star}$ \\
\hline$R^{2}$ & $0.25 \%$ & $0.50 \%$ & $1.67 \%$ & $1.98 \%$ \\
\hline$N$ & 3118 & 3118 & 3118 & 3118 \\
\hline
\end{tabular}

Note: ${ }^{*} p<0.05 ;{ }^{* *} p<0.01 ;{ }^{* * *} p<0.001$.

effects are persistent despite the lower inclination of MNEs towards self-promotion. I did not hypothesize any relationship between post-disaster MNE advertising and relative performance, and the absence of any effect is not surprising.

Overall, these findings validate the assertion that the social restructuring that accompanies a major disaster leads to an increase in philanthropic contribution by MNEs and an increase in the benefits those contributions provide to MNEs.

\section{DISCUSSION AND CONCLUSION}

Natural disasters can wreak havoc on both the physical and the social environment, forcing fundamental social restructuring. This can have large implications for the broadening of ties between MNEs and their host communities. The acute social needs and the social spaces that emerge to support them offer MNEs an opportunity to engage with the local society in a way that may help communities overcome initial skepticism and build trust. The disaster offers a window for MNEs to increase their social engagement, although they are also scrutinized more heavily in terms of their sensitivity to the host environment. In response to the engagement, the host community reduces the social and cultural barriers associated with LOF of the MNE. The result is a mutually beneficial engagement that establishes a new social equilibrium in which foreign firms play a stronger role in social development.

The contrast that we observe between the contributions and performance of MNEs and domestic firms is consistent with my argument that communities continue to differentiate between local and foreign firms in the aftermath of a major disaster, but the nature of this differentiation evolves. Local stakeholders may penalize MNEs for a perceived self-promotional bias but tolerate the same from domestic firms. At the same time, communities appear to confer greater rewards on MNEs for their benevolence but limit support for more economically vulnerable domestic firms. This suggests that local ties are not static; nor are they always favorable to domestic firms. Indeed, the social restructuring associated with disaster reverses the preferential dynamic. Consistent, long-term philanthropic engagement can replenish the ties developed in the aftermath of a disaster, but it is the relative magnitude of contributions that inspires local confidence, yielding greater performance compatibility between MNEs and local communities and ultimately reducing LOF. 
This evidence of a more positive relationship between MNEs and host communities reinforces the idea of a growth in mutual dependence between communities and businesses in the wake of a crisis (see McNamara, Pazzaglia, \& Sonpar, 2015). It also indicates that while local communities are cognizant of MNEs' capabilities, MNEs are also quite aware of their own vulnerability and the need for greater social embeddedness (Granovetter, 1985). Thus, the persistent divide between foreign firms and local communities documented in previous studies (e.g., Amaeshi et al., 2006; Tan, 2009) may not be due to a failure of mutual understanding. Rather, it appears that communities and organizations view social ties as an investment that is difficult to make in the absence of a strong motivator. The shock of a major disaster provides such a justification. This opens up an interesting avenue for further research regarding alternatives to stimulate MNE-community engagement, hopefully in the presence of less extreme conditions than a national disaster (e.g., Mithani, 2016).

A related question pertains to the role of domestic firms. If greater local acceptance of MNEs diminishes the performance superiority of domestic firms, it is quite likely that domestic firms will attempt to create hurdles to make it difficult for MNEs to experience social integration. The context of countries such as India may offer valuable insights in this regard, as market reforms are often accompanied by local initiatives to restrain the influx of foreign equity. It would be an important addition to the literature to understand what social and political actions help local firms maintain or reinforce their domestic superiority. At the same time, my findings for the difference between MNE and domestic firm philanthropy are limited to the four-year period following the disaster. It would be interesting to examine whether MNE-community engagement eventually returns to pre-disaster levels.

Another potential line of research pertains to the effect of business groups. While I found firm-level philanthropy to be associated with business-group contribution only in the long run (i.e., in the 4 th year after the disaster), group-level choices showed no effect on firm performance, suggesting a lack of legitimacy spillover across affiliates. In other words, the firms in a business group appear to be on their own when it comes to the local acceptance of MNEs or the competitive deficiencies of domestic firms. More research can help clarify how social restructuring affects the influence of business groups.
A critical limitation of this research pertains to the generalizability of my findings. With the exception of a few studies (e.g., Muller \& Whiteman, 2009; Oh \& Oetzel, 2011), most of the research on disasters has focused on a single national context. Yet the consistency across findings leads me to believe that my results may not be specific to a single national context. There are likely to be nuances, such as countries where MNEs are more strongly embedded in the local environment or where the effect of advertising may be limited because domestic firms are equally scrutinized in terms of the genuineness of their social intent. I believe that these contextual variations may help extend my findings to provide support for a more generalized theory of corporate social engagement. It can also help bridge my findings with the wider research on the implications of social and cultural differences (Hofstede, 2001).

A second limitation pertains to the causal relationship between disaster and the change in philanthropy and performance. While I have tried to establish the integrity of my findings through several tests, it remains possible that events other than the focal disaster, for example, the changing nature of the economic environment in India which led to a decrease in import restrictions and greater foreign business involvement with local stakeholders, may have also played a role in MNE philanthropy and performance. One way to extend this study would be to parse these differences and understand the extent to which the implications of disaster differ from those arising from the changing nature of the national, and possibly, the global environment. At the same time, it would be interesting to explore alternative approaches that can allow us to establish this causal link more clearly.

Another limitation is that while my use of the Indian context is beneficial in several ways, the country remains exposed to major disasters. While it can make it difficult to establish the persistence of superior MNE contributions, I believe ongoing natural disasters create conditions that enable us to better study firms' philanthropic behavior. They offer an opportunity to examine whether subsequent disasters sharpen the difference between MNE and domestic firm philanthropy (and performance) due to even higher levels of local engagement by foreign firms or minimize the difference because either MNEs fail to sustain their escalated commitment or domestic firms start to match MNE contributions once the economic uncertainty 
passes. In this regard, an interesting extension would be the use of structuration theory to help understand whether changes in MNEs' social considerations are accompanied by changes in political considerations. Such an approach could help develop a comprehensive understanding of how emergent social spaces and the evolution of wider institutional environments may make philanthropy an even more powerful mechanism to mitigate LOF (Luo, 2006).

Finally, my data are limited to philanthropic contributions. It did not allow me to examine the other ways in which firms support local communities. It is quite possible that domestic firms' stronger local ties may lead them to pay greater attention to non-financial contributions. This implies that the relatively lower magnitude of domestic firm philanthropy may be partly compensated by their greater attention to non-financial recovery and relief efforts. Yet my findings show that performance rewards were relatively smaller for domestic firms, indicating that in the event domestic firms were more vested into non-financial contributions, communities found them to be of relatively limited value. This suggests that financial support may be a more effective mechanism to meet local expectations in the event of a crisis. A second implication of my data is that it did not allow me to observe how philanthropic contributions were deployed. It may be that some of the initial increases in MNE contributions were focused on the development of local services and infrastructure that served as a conduit for future contributions. Further research along these lines offers an opportunity to understand the distinct philanthropic mechanisms and goals that come to the fore in the face of a major disaster.

This study makes several important contributions to the literature. First, I show that MNEs use philanthropy as a strategic tool, giving it greater attention and resources at times when their contributions can be an essential part of social and performance improvements. This finding connects with previous research that suggests the salience of philanthropy for foreign firms with the evidence that shows MNEs to be less benevolent than domestic firms in general (Amaeshi et al., 2006; Campbell, Eden, \& Miller, 2012; Tan, 2009). I show that MNEs find social restructuring to be critical times for local attention. In addition to shaping the magnitude and timing of contributions, MNEs' global experiences also make them aware of the danger of self-promotion. Despite limiting selfpromotion, however, MNEs succeed in achieving significant relative gains in performance as a result of their philanthropic contributions.

My second major contribution is an integration of the research on natural disasters and corporate philanthropy with the research on LOF. In particular, the previous research has viewed social and cultural barriers as largely static (Gaur, Kumar, \& Sarathy, 2011; Nachum, 2003) and suggested that, to the extent they can be changed, such change can take several decades (Zaheer \& Mosakowski, 1997). My findings show that the social restructuring that follows a disaster accelerates this process (see Oliver-Smith, 1996). Thus, in this way the rapid change in local expectations and the associated benefits of social compliance make post-disaster philanthropy a valuable mechanism to achieve greater communal congruence.

In addition, I also contribute to the research on corporate philanthropy by showing that the pessimistic view of MNEs may need to be reassessed in the context of their unique skills and contributions. This connects to the more recent research on political CSR, which suggests a broader conceptualization of the social role of MNEs. The concept of political CSR works from the argument that the failure of emerging market governments to ensure the quality of life of its citizens and the need to satisfy diverse social expectations are pushing MNEs towards more active participation in issues of global governance. This participation is translating into an increased emphasis by MNEs on issues such as poverty reduction, infrastructure development, and disaster relief - fields where political vacuum more than economic expectation is the driving force (Scherer \& Palazzo, 2007; Scherer, Palazzo, \& Matten, 2009, 2014). My findings are consistent with this line of thinking, showing that MNEs play a more active social role than do domestic firms after a major disaster. In sum, my demonstration of how firms, and in particular MNEs, contribute to social well-being offers a promising avenue to understand the unique social roles corporations may play in their host communities.

\section{ACKNOWLEDGEMENTS}

The author would like to thank the area editor, Mona Makhija, the anonymous reviewers, and Ann Mooney Murphy for their extremely valuable feedback. 


\section{NOTES}

${ }^{1} \mathrm{My}$ argument for the substitution of philanthropy for advertising expenditure is consistent with evidence that these two expenditure categories are often funded from the same budget (Meyer, Mudambi, \& Narula, 2011; Seifert, Morris, \& Bartkus, 2004; but also see Smith \& Higgins, 2000).

${ }^{2}$ I believe that this difference is likely to subside once MNE commitment to institutional development is sufficiently fulfilled or domestic firms come under social pressure to imitate some of the choices of the foreign firms. I come back to this point in the discussion Sect.

${ }^{3}$ Regulations on imports and foreign equity went through several changes during this period, but in general remained highly restrictive.

${ }^{4}$ Foreign equity exceeding 51 per cent still requires additional approvals, but the process is relatively simple.

${ }^{5}$ The report further noted that "it was during Bhuj [Gujarat] Earthquake, 2001 that the need for a comprehensive strategy and planning targeted at safeguarding the industrial and lifeline infrastructure was underscored" (Issar \& Mathur, 2004: 9). That earthquake and its aftermath led to several major initiatives, including the creation of the National Disaster Management Authority, which has been instrumental in facilitating corporate philanthropic contributions and identifying avenues for long-term engagement by the private sector.

\section{REFERENCES}

Aeberhard, P. 2008. Expectations are changing for disaster relief. Nonprofit and Voluntary Sector Quarterly, 37(1): 17S-24S.

Aldrich, D. P. 2012. Building resilience: Social capital in postdisaster recovery. Chicago: University of Chicago Press.

Amaeshi, K. M., Adi, B. C., Ogbechie, C., \& Amao, O. O. 2006. Corporate social responsibility in Nigeria. Journal of Corporate Citizenship, 2006(24): 83-99.

Asian Development Bank, \& The World Bank. 2001. Gujarat earthquake recovery program: Assessment report. New Delhi: World Bank.

Babiak, K., \& Wolfe, R. 2006. More than just a game? Corporate social responsibility and Super Bowl XL. Sport Marketing Quarterly, 15(4): 214.

Baron, D. P. 2013. Business and its environment. Boston: Pearson Education.

Barton, A. H. 1969. Communities in disaster: A sociological analysis of collective stress situations. Garden City, NJ: Doubleday \& Company.

Bates, F. L., \& Peacock, W. G. 1993. Living conditions, disasters, and development: An approach to cross-cultural comparisons. Athens, GA: University of Georgia Press.

BBC. 2001a. Fresh floods reported in Orissa. July 24. http:// news.bbc.co.uk/1/hi/world/south_asia/1454277.stm.

BBC. 2001 b. Charities plead for India flood aid. July 22. http:// news.bbc.co.uk/1/hi/world/south_asia/1450961.stm.
${ }^{6}$ This is necessary because previous studies have measured LOF by comparing the performance of each MNE with the aggregated performance of all domestic firms and have limited their analysis to single industries. Since my empirical approach seeks to make a firm-to-firm comparison across multiple industries, it is necessary to eliminate the industry-level performance effect and then compare, on average, how each MNE performs relative to each of the domestic firms in my sample. Achieving this analysis required a combined approach.

${ }^{7}$ Although research on LOF has preferred the use of the term performance, I refer to it as relative performance in order to better reflect the theoretical and the operational aspects of the variable.

${ }^{8}$ I did not operationalize a third potential measure of slack, absorbed slack, which includes sales and administrative expenses, due to the absence of a uniform standard for reporting administrative expenses for firms in India.

${ }^{9}$ This is a finer-grained measure than the more commonly used binary indicator of business group affiliation. The results are unaffected if I use business group affiliation.

${ }^{10}$ While the time-invariant variables (including $M N E$ ) were excluded in this analysis, the interactions produced consistent effects.

Bell, R. G., Filatotchev, I., \& Rasheed, A. A. 2012. The liability of foreignness in capital markets: Sources and remedies. Journal of International Business Studies, 43(2): 107-122.

Berkes, F., Colding, J., \& Folke, C. 2002. Navigating socialecological systems: Building resilience for complexity and change. Cambridge, MA: Cambridge University Press.

Berkman, H., Jacobsen, B., \& Lee, J. B. 2011. Time-varying rare disaster risk and stock returns. Journal of Financial Economics, 101(2): 313-332.

Beugelsdijk, S., \& Frijns, B. 2010. A cultural explanation of the foreign bias in international asset allocation. Journal of Banking \& Finance, 34(9): 2121-2131.

Bhanji, Z., \& Oxley, J. E. 2013. Overcoming the dual liability of foreignness and privateness in international corporate citizenship partnerships. Journal of International Business Studies, 44(4): 290-311.

Bin, O., \& Edwards, B. 2009. Social capital and business giving to charity following a natural disaster: An empirical assessment. The Journal of Socio-Economics, 38(4): 601-607.

Brik, A. B., Rettab, B., \& Mellahi, K. 2011. Market orientation, corporate social responsibility, and business performance. Journal of Business Ethics, 99(3): 307-324.

Brown, W. O., Helland, E., \& Smith, J. K. 2006. Corporate philanthropic practices. Journal of Corporate Finance, 12(5): 855-877. 
Campbell, J. T., Eden, L., \& Miller, S. R. 2012. Multinationals and corporate social responsibility in host countries: Does distance matter? Journal of International Business Studies, 43(1): 84-106.

Carrigan, M. 1997. The great corporate give-away: Can marketing do good for the "do-gooders"? European Business Journal, 9(4): 40-46.

Chacar, A., \& Vissa, B. 2005. Are emerging economies less efficient? Performance persistence and the impact of business group affiliation. Strategic Management Journal, 26(10): 933-946.

Chamlee-Wright, E., \& Storr, V. H. 2011. Social capital as collective narratives and post-disaster community recovery. The Sociological Review, 59(2): 266-282.

Chari, M. D., \& David, P. 2012. Sustaining superior performance in an emerging economy: An empirical test in the Indian context. Strategic Management Journal, 33(2): 217-229.

Child, J., \& Tsai, T. 2005. The dynamic between firms' environmental strategies and institutional constraints in emerging economies: Evidence from China and Taiwan. Journal of Management Studies, 42(1): 95-125.

Chittoor, R., Sarkar, M. B., Ray, S., \& Aulakh, P. S. 2009. Thirdworld copycats to emerging multinationals: Institutional changes and organizational transformation in the Indian pharmaceutical industry. Organization Science, 20(1): 187-205.

Christmann, P., \& Taylor, G. 2001. Globalization and the environment: Determinants of firm self-regulation in China. Journal of International Business Studies, 32(3): 439-458.

Cram, D. P., Karan, V., \& Stuart, I. 2009. Three threats to validity of choice-based and matched-sample studies in accounting research. Contemporary Accounting Research, 26(2): 477-516.

Crampton, W., \& Patten, D. 2008. Social responsiveness, profitability and catastrophic events: Evidence on the corporate philanthropic response to 9/11. Journal of Business Ethics, 81(4): 863-873

Crilly, D., Ni, N., \& Jiang, Y. 2016. Do-no-harm versus do-good social responsibility: Attributional thinking and the liability of foreignness. Strategic Management Journal, 37(7): 1316-1329.

Dahan, N., Doh, J., \& Guay, T. 2006. The role of multinational corporations in transnational institution building: A policy network perspective. Human Relations, 59(11): 1571-1600.

DelVecchio, D., Henard, D. H., \& Freling, T. H. 2006. The effect of sales promotion on post-promotion brand preference: A meta-analysis. Journal of Retailing, 82(3): 203-213.

Doukas, J. A., \& Lang, L. H. 2003. Foreign direct investment, diversification and firm performance. Journal of International Business Studies, 34(2): 153-172.

Drabek, T. E., \& Key, W. H. 1976. The impact of disaster on primary group linkages. Mass Emergencies, 1(2): 89-105.

Drumwright, M. E. 1996. Company advertising with a social dimension: The role of noneconomic criteria. The Journal of Marketing, 60(4): 71-87.

Dunning, J. H., \& Lundan, S. M. 2008. Multinational enterprises and the global economy. Northampton, MA: Edward Elgar Publishing.

Eden, L., \& Miller, S. R. 2004. Distance matters: Liability of foreignness, institutional distance and ownership strategy. Advances in International Management, 16: 187-221.

Etzioni, A. 1975. Comparative analysis of complex organizations (revised edn). New York: The Free Press.

European Foundation Centre and Council on Foundations. 2007. Disaster grantmaking: A practical guide for foundations and corporations. Bruxelles: European Foundation Centre.

File, K. M., \& Prince, R. A. 1998. Cause related marketing and corporate philanthropy in the privately held enterprise. Journal of Business Ethics, 17(14): 1529-1539.

Fisher, K. E., \& Naumer, C. M. 2006. Information grounds: Theoretical basis and empirical findings on information flow in social settings. In A. Spink \& C. Cole(Eds), New directions in human information behavior: 93-111. Amsterdam: Springer-Kluwer.

Fry, L. W., Keim, G. D., \& Meiners, R. E. 1982. Corporate contributions: Altruistic or for-profit? Academy of Management Journal, 25(1): 94-106.
Galaskiewicz, J. 1997. An urban grants economy revisited: Corporate charitable contributions in the twin cities, 1979-81, 1987-89. Administrative Science Quarterly, 42(3): 445-471.

Gaur, A. S., Kumar, V., \& Sarathy, R. 2011. Liability of foreignness and internationalisation of emerging market firms. Advances in International Management, 24: 211-233.

Geppert, M., Matten, D., \& Walgenbach, P. 2006. Transnational institution building and the multinational corporation: An emerging field of research. Human Relations, 59(11): 1451-1465.

Ghoul, S. E., Guedhami, O., \& Kim, Y. 2017. Country-level institutions, firm value, and the role of corporate social responsibility initiatives. Journal of International Business Studies, 48(3): 360-385.

Gilbert, C. 1998. Studying disaster: Changes in the main conceptual tools. In E. L. Quarantelli (Ed.): What is a disaster? Perspectives on the question: 11-18. London: Routledge.

Glynn, M. A. 2008. Configuring the field of play: How hosting the Olympic Games impacts civic community. Journal of Management Studies, 45(6): 1117-1146.

Glynn, S. A., Busch, M. P., Schreiber, G. B., Murphy, E. L., Wright, D. J., Tu, Y., et al. 2003. Effect of a national disaster on blood supply and safety: The September 11 experience. JAMA 289(17): 2246-2253.

Godfrey, P. C. 2005. The relationship between corporate philanthropy and shareholder wealth: A risk management perspective. Academy of Management Review, 30(4): 777-798.

Gopal, S. 1984. Jawaharlal Nehru: A Biography Volume Three 1956-1964. Cambridge, MA: Harvard University Press.

Granovetter, M. 1985. Economic action and social structure: The problem of embeddedness. American Journal of Sociology, 91(3): 481-510.

Harjoto, M. A., \& Jo, H. 2011. Corporate governance and CSR nexus. Journal of Business Ethics, 100(1): 45-67.

Henderson, J. C. 2007. Corporate social responsibility and tourism: Hotel companies in Phuket, Thailand, after the Indian Ocean tsunami. International Journal of Hospitality Management, 26(1): 228-239.

Henisz, W. J., Dorobantu, S., \& Nartey, L. J. 2014. Spinning gold: The financial returns to stakeholder engagement. Strategic Management Journal, 35(12): 1727-1748.

Hindu. 2001. Bihar flood toll mounts to 89. Septermber 17. http:// www.thehindu.com/2001/09/17/stories/14172043.htm.

Hofstede, G. H. 2001. Culture's consequences: Comparing values, behaviors, institutions, and organizations across nations. Thousand Oaks, CA: Sage.

Horlick-Jones, T. 1995. Modern disasters as outrage and betrayal. International Journal of Mass Emergencies and Disasters, 13(3): 305-315.

Indian Red Cross Society. 2002. India Floods 2001: Final Report (appeal no. 21/2001). November 20. www.ifrc.org/docs/ appeals/21/2001fr.pdf.

Issar, R., \& Mathur, N. B. 2004. Disaster risk management and the role of corporate sector: The Indian perspective. New Delhi: National Disaster Division, Ministry of Home Affairs.

Jenkins, R. 1999. Democratic politics and economic reform in India. Cambridge, MA: Cambridge University Press.

Johnson, C., Dowd, T. J., \& Ridgeway, C. L. 2006. Legitimacy as a social process. Annual Review of Sociology, 32: 53-78.

Kacperczyk, A. 2009. With greater power comes greater responsibility? Takeover protection and corporate attention to stakeholders. Strategic Management Journal, 30(3): 261-285.

Khanna, T., \& Palepu, K. 2000. Is group affiliation profitable in emerging markets? An analysis of diversified Indian business groups. Journal of Finance, 55(2): 867-891.

Khanna, T., \& Palepu, K. G. 2013. Winning in emerging markets: A road map for strategy and execution. Boston: Harvard Business Press.

Kostova, T., \& Zaheer, S. 1999. Organizational legitimacy under conditions of complexity: The case of the multinational enterprise. Academy of Management Review, 24(1): 64-81. 
Kreps, G. A. 1985. Disaster and the social order. Sociological Theory, 3(1): 49-64.

Lamin, A. 2013. Business groups as information resource: An investigation of business group affiliation in the Indian software services industry. Academy of Management Journal, 56(5): 1487-1509.

Lefebvre, H. 2009. State, space, world: Selected essays. S. Elden \& N. Brenner (Eds.), G. Moore (Trans). Minneapolis: University of Minnesota Press.

Lines, V. L. 2004. Corporate reputation in Asia: Looking beyond bottom-line performance. Journal of Communication Management, 8(3): 233-245.

Luo, Y. 2006. Political behavior, social responsibility, and perceived corruption: A structuration perspective. Journal of International Business Studies, 37(6): 747-766.

Mata, J., \& Freitas, E. 2012. Foreignness and exit over the life cycle of firms. Journal of International Business Studies, 43(7): 615-630.

McNamara, P., Pazzaglia, F., \& Sonpar, K. 2015. Large-scale events as catalysts for creating mutual dependence between social ventures and resource providers. Journal of Management (Forthcoming). doi:10.1177/0149206314563983.

McWilliams, A., \& Siegel, D. 2000. Corporate social responsibility and financial performance: Correlation or misspecification? Strategic Management Journal, 21(5): 603-609.

McWilliams, A., \& Siegel, D. 2001. Corporate social responsibility: A theory of the firm perspective. Academy of Management Review, 26(1): 117-127.

Meyer, K. E., Mudambi, R., \& Narula, R. 2011. Multinational enterprises and local contexts: The opportunities and challenges of multiple embeddedness. Journal of Management Studies, 48(2): 235-252.

Mezias, J. M. 2002. Identifying liabilities of foreignness and strategies to minimize their effects: The case of labor lawsuit judgments in the United States. Strategic Management Journal, 23(3): 229-244.

Michel, A., \& Shaked, I. 1986. Multinational corporations vs. domestic corporations: Financial performance and characteristics. Journal of International Business Studies, 17(3): 89-100.

Miller, D., Lee, J., Chang, S., \& Le Breton-Miller, I. 2009. Filling the institutional void: The social behavior and performance of family vs non-family technology firms in emerging markets. Journal of International Business Studies, 40(5): 802-817.

Miller, S. R., \& Parkhe, A. 2002. Is there a liability of foreignness in global banking? An empirical test of banks' X-efficiency. Strategic Management Journal, 23(1): 55-75.

Mirza, M. M. Q., Ahmed, A. U., \& Ahmad, Q. K. 2007. Interlinking of rivers in India: Issues and concerns. New York: CRC Press.

Mishina, Y., Block, E. S., \& Mannor, M. J. 2012. The path dependence of organizational reputation: How social judgment influences assessments of capability and character. Strategic Management Journal, 33(5): 459-477.

Mitchell, J. K. 2006. The primacy of partnership: Scoping a new national disaster recovery policy. The Annals of the American Academy of Political and Social Science, 604(1): 228-255.

Mithani, M. A. 2016. Innovation and CSR: Do they go well together? Long Range Planning. doi:10.1016/j.Irp.2016.08.002.

Moir, L., \& Taffler, R. 2004. Does corporate philanthropy exist? Business giving to the arts in the UK. Journal of Business Ethics, 54(2): 149-161.

Muller, A., \& Kräussl, R. 2011. Doing good deeds in times of need: A strategic perspective on corporate disaster donations. Strategic Management Journal, 32(9): 911-929.

Muller, A., \& Whiteman, G. 2009. Exploring the geography of corporate philanthropic disaster response: A study of Fortune Global 500 firms. Journal of Business Ethics, 84(4): 589-603.

Nachum, L. 2003. Liability of foreignness in global competition? Financial service affiliates in the city of London. Strategic Management Journal, 24(12): 1187-1208.

Oh, C. H., \& Oetzel, J. 2011. Multinationals' response to major disasters: How does subsidiary investment vary in response to the type of disaster and the quality of country governance? Strategic Management Journal, 32(6): 658-681.

Oliver-Smith, A. 1996. Anthropological research on hazards and disasters. Annual Review of Anthropology, 25: 303-328.

Panagariya, A. 2008. India: The emerging giant. Oxford: Oxford University Press.

Pant, A., \& Ramachandran, J. 2017. Navigating identity duality in multinational subsidiaries: A paradox lens on identity claims at Hindustan Unilever 1959-2015. Journal of International Business Studies. doi:10.1057/s41267-017-0076-x.

Patten, D. M. 2008. Does the market value corporate philanthropy? Evidence from the response to the 2004 tsunami relief effort. Journal of Business Ethics, 81(3): 599-607.

Pearce, L. 2003. Disaster management and community planning, and public participation: How to achieve sustainable hazard mitigation. Natural Hazards, 28(2-3): 211-228.

Pescosolido, B. A., \& Rubin, B. A. 2000. The web of group affiliations revisited: Social life, postmodernism, and sociology. American Sociological Review, 65(1): 52-76.

Quarantelli, E. L. 2000. Disaster research. In H. E. F. Borgatta \& R. J. V. Montgomery (Eds), Encyclopedia of sociology (2nd ed.): 681-688. New York: Macmillan.

Quarantelli, E. L., \& Dynes, R. R. 1977. Response to social crisis and disaster. Annual Review of Sociology, 3: 23-49.

Reeb, D., Sakakibara, M., \& Mahmood, I. P. 2012. From the editors: Endogeneity in international business research. Journal of International Business Studies, 43(3): 211-218.

Roberts, P. S. 2010. Private choices, public harms: The evolution of national disaster organizations in the United States. In A. Lakoff (Ed.), Disaster and the politics of intervention: 41-69. New York: Columbia University Press.

Roy, W. G. 1999. Socializing capital: The rise of the large industrial corporation in America. Princeton, NJ: Princeton University Press.

Rugman, A. M. 2005. The regional multinationals: MNEs and "global" strategic management. Cambridge, MA: Cambridge University Press.

Savage, M., \& Silva, E. B. 2013. Field analysis in cultural sociology. Cultural Sociology, 7(2): 111-126.

Scherer, A. G., \& Palazzo, G. 2007. Toward a political conception of corporate responsibility: Business and society seen from a Habermasian perspective. Academy of Management Review, 32(4): 1096-1120.

Scherer, A. G., Palazzo, G., \& Matten, D. 2009. Introduction to the Special Issue: Globalization as a challenge for business responsibilities. Business Ethics Quarterly, 19(3): 327-347.

Scherer, A. G., Palazzo, G., \& Matten, D. 2014. The business firm as a political actor: A new theory of the firm for a globalized world. Business \& Society, 53(2): 143-156.

Seifert, B., Morris, S. A., \& Bartkus, B. R. 2004. Having, giving, and getting: Slack resources, corporate philanthropy, and firm financial performance. Business \& Society, 43(2): 135-161.

Servaes, H., \& Tamayo, A. 2013. The impact of corporate social responsibility on firm value: The role of customer awareness. Management Science, 59(5): 1045-1061.

Shan, L., \& Gong, S. X. 2012. Investor sentiment and stock returns: Wenchuan Earthquake. Finance Research Letters, 9(1): 36-47.

Siegel, D. S., \& Vitaliano, D. F. 2007. An empirical analysis of the strategic use of corporate social responsibility. Journal of Economics \& Management Strategy, 16(3): 773-792.

Singh, K. 2005. Foreign direct investment in India: A critical analysis of FDI from 1991-2005. SSRN Scholarly Paper No. ID 822584. Rochester, NY: Social Science Research Network.

Smith, W., \& Higgins, M. 2000. Cause-related marketing: Ethics and the ecstatic. Business \& Society, 39(3): 304-322.

Strike, V. M., Gao, J., \& Bansal, P. 2006. Being good while being bad: Social responsibility and the international diversification of US firms. Journal of International Business Studies, 37(6): 850-862.

Surroca, J., Tribó, J. A., \& Waddock, S. 2010. Corporate responsibility and financial performance: The role of intangible resources. Strategic Management Journal, 31(5): 463-490. 
Tan, J. 2009. Institutional structure and firm social performance in transitional economies: Evidence of multinational corporations in China. Journal of Business Ethics, 86: 171-189.

Thomalla, F., \& Schmuck, H. 2004. 'We All Knew that a Cyclone Was Coming': Disaster preparedness and the cyclone of 1999 in Orissa, India. Disasters, 28(4): 373-387.

Tilcsik, A., \& Marquis, C. 2013. Punctuated generosity: How mega-events and natural disasters affect corporate philanthropy in US communities. Administrative Science Quarterly, 58(1): 111-148.

Valente, M., \& Crane, A. 2010. Public responsibility and private enterprise in developing countries. California Management Review, 52(3): 52-78.

Varadarajan, P. R., \& Menon, A. 1988. Cause-related marketing: A coalignment of marketing strategy and corporate philanthropy. Journal of Marketing, 52(3): 58-74

Vissa, B., Greve, H. R., \& Chen, W.-R. 2010. Business group affiliation and firm search behavior in India: Responsiveness and focus of attention. Organization Science, 21(3): 696-712.

Wagner, M. 2010. The role of corporate sustainability performance for economic performance: A firm-level analysis of moderation effects. Ecological Economics, 69(7): 1553-1560.

Walker, H. A. 2004. Beyond power and domination: Legitimacy and formal organizations. In C. Johnson (Ed.), Legitimacy processes in organizations: 239-271. Bingley: Emerald Group Publishing.

Walker, H. A., \& Zelditch, M. 1993. Power, legitimacy, and the stability of authority: A theoretical research program. In J. Berger \& M. Zelditch (Eds), Theoretical research programs:
Studies in the growth of theory: 364-381. Stanford, CA: Stanford University Press.

Webb, G. R., Tierney, K., \& Dahlhamer, J. 2000. Businesses and disasters: Empirical patterns and unanswered questions. Natural Hazards Review, 1(2): 83-90.

White, S., \& Lang, H. 2012. Corporate engagement in natural disaster response: Piecing together the value chain. Washington, DC: Rowman \& Littlefield Publishers.

Zaheer, S. 1995. Overcoming the liability of foreignness. Academy of Management Journal, 38(2): 341-363.

Zaheer, S. 2002. The liability of foreignness, redux: A commentary. Journal of International Management, 8(3): 351-358.

Zaheer, S., \& Mosakowski, E. 1997. The dynamics of the liability of foreignness: A global study of survival in financial services. Strategic Management Journal, 18(6): 439-463.

Zelditch, M. 2001. Theories of legitimacy, In I. T. lost \& B. Major (Eds), The psychology of legitimacy: Emerging perspectives on ideology, justice, and intergroup relations: 33-53. New York: Cambridge University Press.

Zhang, J., \& Luo, X. R. 2013. Dared to care: Organizational vulnerability, institutional logics, and $\mathrm{MNCs}^{\prime}$ social responsiveness in emerging markets. Organization Science, 24(6): 1742-1764.

Zhang, R., Zhu, J., Yue, H., \& Zhu, C. 2010. Corporate philanthropic giving, advertising intensity, and industry competition level. Journal of Business Ethics, 94(1): 39-52.

\section{APPENDIX A: THE IMPACT OF NATURAL DISASTERS (EARTHQUAKES AND FLOODS) IN INDIA}

\begin{tabular}{lrrlrl}
\hline Year & Dead + Injured & Dead & Injured & Displaced & Damage (US\$) \\
\hline 1998 & 1,368 & 1,368 & - & 145,000 & $530,000,000$ \\
1999 & 10,297 & 9,903 & 394 & $10,105,400$ & $2,370,000,000$ \\
2000 & 1,090 & 1,090 & - & $3,059,000$ & $415,000,000$ \\
2001 & 187,464 & 20,628 & 166,836 & $4,103,995$ & $2,847,038,928$ \\
2002 & 261 & 261 & - & $6,269,498$ & No estimates \\
2003 & 429 & 429 & - & $3,016,800$ & $55,000,000$ \\
\hline
\end{tabular}

Source: Dartmouth Flood Observatory and the National Oceanic and Atmospheric Association.

\section{APPENDIX B: PROPORTION OF SAMPLE LOCATED IN THE IMPACT ZONE}

\begin{tabular}{|c|c|c|c|c|c|}
\hline City & State & MNE & Domestic & $n$ & $\%$ Tota \\
\hline Ahmedabad & Gujarat & 11 & 68 & 79 & 2.53 \\
\hline Surat & Gujarat & 7 & 8 & 15 & 0.48 \\
\hline Jamnagar & Gujarat & 8 & 0 & 8 & 0.26 \\
\hline Guntur & Andhra Pradesh & 0 & 8 & 8 & 0.26 \\
\hline Chittoor & Andhra Pradesh & 0 & 4 & 4 & 0.13 \\
\hline Gandhinagar & Gujarat & 0 & 4 & 4 & 0.13 \\
\hline Nellore & Andhra Pradesh & 0 & 4 & 4 & 0.13 \\
\hline Patna & Bihar & 0 & 3 & 3 & 0.10 \\
\hline Total & & 26 & 99 & 125 & 4.01 \\
\hline
\end{tabular}


APPENDIX C: SUBSAMPLE MEANS FOR MATCHED SAMPLE

\begin{tabular}{lrrr}
\hline Variables & MNE & Domestic & $t$-value \\
\hline Philanthropic contribution & 0.42 & 0.38 & 0.04 \\
Advertising expense & 55.07 & 35.66 & 19.41 \\
Relative performance & -0.03 & 0.12 & $-0.15^{*}$ \\
Sales (Ln) & 6.67 & 6.84 & -0.16 \\
Exports/sales & 0.11 & 0.13 & -0.03 \\
Unabsorbed slack & 0.86 & 0.89 & -0.02 \\
Potential slack & 2.34 & 1.23 & 1.12 \\
R\&D expense & 8.91 & 6.93 & 1.98 \\
Experience & 27.54 & 33.75 & $-6.21^{* *}$ \\
BG philanthropic contribution & 0.10 & 0.29 & $-0.19+$ \\
Impact zone & 0.02 & 0.09 & $-0.07^{* *}$ \\
\hline
\end{tabular}

Note: ${ }^{+} p<0.10 ;{ }^{*} p<0.05 ;{ }^{* *} p<0.01$.

\section{APPENDIX D: GLS RANDOM EFFECTS REGRESSION MODELS FOR MATCHED SAMPLE}

\begin{tabular}{|c|c|c|c|c|}
\hline \multirow[t]{2}{*}{ Variable } & \multicolumn{3}{|c|}{ Philanthropic contribution } & \multirow{2}{*}{$\begin{array}{l}\text { Relative performance } \\
\qquad t+1\end{array}$} \\
\hline & $t+1$ & $t+2$ & $t+3$ & \\
\hline MNE $\times$ period & $56.78+$ & $67.94+$ & $82.58+$ & -2.83 \\
\hline MNE $\times$ period $\times$ advertising & $-3.60^{\star *}$ & $-3.14^{\star}$ & $-5.54^{\star \star}$ & 0.31 \\
\hline MNE $\times$ period $\times$ philanthropic contribution & & & & $26.11^{* *}$ \\
\hline MNE & 2.59 & 8.74 & 21.03 & $-19.50^{* *}$ \\
\hline Period & 1.81 & 13.79 & 22.51 & 0.50 \\
\hline Advertising expense & $0.16^{*}$ & 0.15 & $0.24+$ & 0.03 \\
\hline Philanthropic contribution & & & & $-5.11^{* * *}$ \\
\hline MNE $\times$ advertising & -0.14 & 0.78 & 0.99 & -0.08 \\
\hline Period $\times$ advertising & $1.73^{* *}$ & $1.39 *$ & $3.04^{\star * *}$ & -0.07 \\
\hline MNE $\times$ philanthropic contribution & & & & 3.42 \\
\hline Period $\times$ philanthropic contribution & & & & $27.66^{\star * \star}$ \\
\hline Sales $(\operatorname{Ln})$ & 17.05 & $20.20+$ & $24.51+$ & $11.24^{* * *}$ \\
\hline Exports/sales & -3.33 & -6.64 & -7.01 & -9.53 \\
\hline Unabsorbed slack & -7.52 & -10.17 & 1.59 & -2.99 \\
\hline Potential slack & 0.09 & 0.14 & 0.18 & -0.07 \\
\hline R\&D expense & 0.24 & 0.18 & 0.31 & $0.26^{*}$ \\
\hline Experience & -1.30 & -1.41 & -1.37 & -0.02 \\
\hline BG philanthropic contribution & -0.13 & 1.15 & 5.59 & -0.21 \\
\hline Impact zone & -26.56 & -30.49 & -13.2 & -7.59 \\
\hline Constant & -67.91 & -94.01 & -147.94 & $-65.54^{\star}$ \\
\hline Industry dummies & $\mathrm{Y}$ & $\mathrm{Y}$ & Y & $\mathrm{Y}$ \\
\hline Wald $\chi^{2}$ & $62.89^{*}$ & $58.20^{*}$ & $70.94^{* *}$ & $142.80^{* * *}$ \\
\hline$R^{2}$ & $2.91 \%$ & $3.61 \%$ & $6.16 \%$ & $8.82 \%$ \\
\hline$N$ & 424 & 530 & 636 & 424 \\
\hline
\end{tabular}

Note: ${ }^{+} p<0.10 ;{ }^{*} p<0.05 ;{ }^{* *} p<0.01 ;{ }^{* * *} p<0.001$. 


\section{APPENDIX E: GLS RANDOM EFFECTS REGRESSION MODEL}

\begin{tabular}{|c|c|}
\hline Variable & $\begin{array}{l}\text { Philanthropic } \\
\text { contribution }\end{array}$ \\
\hline MNE $\times$ Period & $10.12^{*}$ \\
\hline MNE $\times$ Period $\times$ Advertising & $-1.19^{* * *}$ \\
\hline MNE $\times$ Period $\times$ Sales promotional discount & $24.37^{\star \star *}$ \\
\hline MNE & $12.97^{*}$ \\
\hline Period & 0.48 \\
\hline Advertising expense & $0.45^{* * *}$ \\
\hline Sales promotional discount & $7.33^{* * *}$ \\
\hline MNE $\times$ Advertising & $-0.50 * *$ \\
\hline Period $\times$ Advertising & $0.81^{* * *}$ \\
\hline MNE $\times$ Sales promotional discount & 4.39 \\
\hline Period $\times$ Sales promotional discount & $5.03^{* * *}$ \\
\hline Sales $(\operatorname{Ln})$ & 1.41 \\
\hline Exports/sales & 2.20 \\
\hline Unabsorbed slack & 0.04 \\
\hline Potential slack & -0.002 \\
\hline$R \& D$ expense & $0.60 * * *$ \\
\hline Experience & -0.17 \\
\hline BG philanthropic contribution & 0.09 \\
\hline Impact zone & -12.20 \\
\hline Industry Dummies & $\mathrm{Y}$ \\
\hline Wald $\chi^{2}$ & $1555.22^{\star \star *}$ \\
\hline$R^{2}$ & $26.35 \%$ \\
\hline$N$ & 3118 \\
\hline
\end{tabular}

Note: ${ }^{*} p<0.05 ;{ }^{* *} p<0.01 ;{ }^{* * *} p<0.001$.

\section{ABOUT THE AUTHOR}

Murad A Mithani is an Assistant Professor at the Stevens Institute of Technology. His research focuses on corporate social responsibility, strategic change, and organizational politics. He received his Ph.D in Management from the Rensselaer Polytechnic Institute. Prior to his Ph.D, He worked for more than 10 years managing and consulting for-profit and non-profit organizations.

Open Access This article is distributed under the terms of the Creative Commons Attribution 4.0 International License (http://creativecommons. org/licenses/by/4.0/), which permits unrestricted use, distribution, and reproduction in any medium, provided you give appropriate credit to the original author(s) and the source, provide a link to the Creative Commons license, and indicate if changes were made. 